\title{
LANDASAN ONTOLOGIS, EPISTEMOLOGIS, DAN AKSIOLOGIS DALAM PENELITIAN PSIKOLOGI
}

\author{
M. Nursalim \\ Universitas Muhammadiyah Lampung \\ nursalimmalay@yahoo.com
}

\begin{abstract}
Abstrak
Seperti halnya dengan penelitian pada disiplin ilmu lainnya, penelitian dalam ilmu psikologi tidak akan pernah dapat lepas dari filsafat ilmu. Artikel ini mengkaji landasan ontologis, epistemologis, dan aksiologis dalam penelitian Psikologi. Secara ontologis, objek formalnya adalah jiwa yang dimanifestasikan dalam perilaku. Secara epistemologis, penelitian psikologi berkembang pesat dengan pendekatan kuantitatif sehingga psikologi menjadi ilmu terapan yang dapat memecahkan problema manusia saat ini, seperti penggunaan alat tes bidang pendidikan, bidang kesehatan, hukum dan lain-lain. Namun pengkuantifikasian manusia ini, menjadikan penelitian psikologi tidak utuh dan dingin dalam memandang manusia. Sehingga lahirlah pendekatan kualitatif untuk lebih memahami hakekat manusia. Sedangkan peranan filsafat ilmu dalam penelitian psikologi adalah mendampingi pengguna hasil penelitian ilmu psikologi secara kritis sehingga peneliti mampu menggunakannya untuk kesejahteraan umat manusia. Pendekatan kuantitatif, dengan segala kelebihan dan keterbatasannya, dapat diintegrasikan dengan pendekatan kualitatif supaya lebih memahami manusia secara utuh. Untuk mencapai kebenaran, peneliti hendaknya memiliki kejujuran sebagai etika penelitian yang diintegrasikan ke dalam kepribadiannya.
\end{abstract}

\section{Abstract}

THE ONTOLOGICAL, EPISTEMOLOGICAL, AND AXIOLOGICAL BASES OF THE RESEARCH IN PSYCHOLOGY. Like any researchs in other disciplines, research in psychology can never be separated from the philosophy of science. This article examines the ontological, epistemological, and axiological fondation in psychology research. Ontologically, the formal object in psychological research is the soul that is manifested in behavior. 
Epistemologically, psychological research is growing rapidly with a quantitative approach to the level that psychology becomes an applied science that can solve human problems. Unfortunately, the quantifification of human behavior would make the psychological research is not intact and looks cool in view of humans. Accordingly, the qualitative approach is born to better understand about human nature. The role of the philosophy of science in psychology research is assisting the researcher to able to use it for the welfare of mankind. The quantitative approach, with all its advantages and limitations, can be integrated with a qualitative approach in order to better understand the human being as a whole. To reach the truth, a researchers should have honesty as a part of research ethics which are integrated into his personality.

Kata Kunci : Filsafat Ilmu, Psikologi, Kuantitatif, Kualitatif.

\section{A. Pendahuluan}

Psikologi sebagai suatu ilmu sosial yang mempelajari tentang perilaku manusia dengan berbagai karakteristiknya merupakan pengetahuan yang diperoleh dengan penelitianpenelitian ilmiah. Melalui pendekatan ilmiah akan diperoleh kesimpulan yang serupa hampir bagi setiap orang karena pendekatan tersebut tidak diwarnai oleh keyakinan, keinginan serta perasaan pribadi. Cara pengambilan keputusan tidak secara subyektif tetapi obyektif, karena itulah sifat obyektif akan selalu dituntut dalam suatu ilmu. Penelitian sebagai kegiatan sentral dari suatu perguruan tinggi idealnya mencerminkan ciri-ciri keilmuan. Apalagi institusi pendidikan cenderung menjadikan riset sebagai tolak ukur kemajuan suatu perguruan tinggi.

Menurut faham Yunani, bentuk tertinggi dari ilmu adalah kebijaksanaan. Di sini terlihatlah suatu sikap etika. ${ }^{1}$ Di dalam ilmu selalu diperlukan kejujuran: kejujuran ilmiah. Hasil penelitian harus dilaporkan apa adanya, kalau negatif harus dikatakan negatif, begitu pula sumber gagasan dan teori yang dipakai harus ditunjukan siapa pencetusnya. Plagiatisme menjadi sesuatu yang amat tercela, sehingga seorang dosen yang melakukan plagiatisme akan diminta mengundurkan diri karena tidak sesuai dengan kaidah keilmuan. Didalam iklim ilmiah yang penuh kejujuran

${ }^{1}$ N. Daldjoeni, Hubungan etika dengan ilmu dalam sebuah kumpulan karangan tentang hakekat ilmu, (Jakarta: Yayasan Obor Indonesia , 1992), h. 233. 
biasanya penuh dengan kata-kata yang batasannya jelas, tegas sehingga apa yang ingin disampaikan tidak mudah disalah interpretasikan. $^{2}$

Metode pendekatan keilmuan dalam psikologi, yaitu kualitatif dan kuantitatif, keduanya memiliki kelebihan dan keterbatasan dalam mencari hakekat kebenaran ilmu, sehingga kita tidak akan mendewa-dewakan salah satu pendekatan tersebut. Hakekat ilmu tidak boleh berhubungan dengan titel, profesi atau kedudukan; hakekat ilmu ditentukan oleh cara berfikir yang dilakukan menurut persyaratan keilmuan, sehingga ilmu tidak ditempatkan pada suatu instruktur feodalisme yang terselubung. Ilmu bersifat terbuka, demokratis dan menjunjung kebenaran di atas segala-galanya. ${ }^{3}$ Ilmu yang mengajari kita bahwa tidak ada sebuah teori ataupun gagasan yang tidak boleh dibantah. Filsafat ilmu, moral dan etika ilmu idealnya seiring dengan ilmu itu sendiri hingga tercapai kemakmuran dan kehormatan bangsa.

\section{B. Pengertian Psikologi Sebagai Suatu Ilmu}

Ditinjau dari asal katanya, psikologi berasal dari kata 'psyche' dan 'logos' yang berarti ilmu jiwa atau ilmu yang mempelajari tentang perilaku manusia. Hal ini dikarenakan jiwa memiliki arti yang abstrak dan sukar untuk dipelajari secara obyektif, juga keadaan jiwa seseoranglah yang melatar belakangi timbulya hampir seluruh perilaku manusia. ${ }^{4}$ Sekarang ini walaupun para sarjana sudah sepakat tentang obyek materil psikologi adalah perilaku, tetapi mengenai arti perilaku itu sendiri dan perilaku yang bagaimana yang dipelajari psikologi masih menjadi bahan perbincangan. Para ahli yang menitik-beratkan pandangan psikoanalisa dalam uraiannya mengenai perilaku banyak memperhatikan aspek-aspek ketidak-sadaran, sedangkan ahli yang berpandangan behavioristik lebih memperhatikan segisegi obyektif yang dapat diamati pada perilaku. Adapun beda pandangan ini menyebabkan timbulnya macam-macam usaha

${ }^{2}$ Djohansjah Marzoeki, Jurnal Anima, Volume. XIII-No49, 1977, h. 8.

${ }^{3} J u j u n$ S. Suriasumantri, Tentang Hakekat ilmu, (Jakarta: Yayasan Obor Indonesia, 1992), h. 9.

${ }^{4}$ Singgih Dirgagunarsa, Pengantar Psikologi, (Jakarta: Mutiara, 1983), h. 9. 
merumuskan psikologi dari latar belakang keilmiahannya masingmasing.

Usaha merumuskan psikologi ini dengan tidak membatasi perilaku pada manusia saja, melainkan juga pada perilaku hewan. Psikologi yang mempelajari perilaku hewan dikenal dengan nama 'Animal Psychology' karena hewan ini umumnya dipelajari dalam rangka eksperimen untuk mengetahui perilaku dasarnya, maka animal physcology disebut juga dengan istilah yang lebih netral yaitu "Experimental Psychology", jadi psychology bukan hanya tentang "human behaviour" tetapi juga menyangkut "Living Organism".

Tokoh-tokoh yang mempelajari psikologi hewan antara lain: I.P. Pavlov dengan "Conditioned reflek”, B.F. Skinner dengan "Skinner box dan Instrumental learning" serta E.L. Thorndike terkenal dengan "maze learning dan law of effectnya". Berkembangnya psikologi eksperimen dengan dilakukannya percobaan yang bersifat kuantitatif, maka psikologi tidak lagi berhubungan dengan hal-hal yang abstrak saja melainkan dengan hal-hal yang faktual. ${ }^{5}$ Hasil-hasil penelitian pada hewan dapat diterapkan pada manusia dan ini merupakan manfaat dari psikologi hewan yaitu dapat lebih bebas melakukan percobaan pada hewan yang apabila diterapkan pada manusia menjadi tidak berperikemanusiaan.

Ilmu pengetahuan mengenal apa yang disebut 'Ilmiah Universal' yaitu dalil-dalil, pengertian-pengertian ataupun aksioma-aksioma yang berlaku umum. Psikologi sebagai ilmu juga memiliki sifat ini dan hal ini berarti bahwa psikologi harus mempelajari manusia dalam pengertian-pengertian yang berlaku umum disamping mempelajarinya sebagai totalitas kepribadian yang unik. Psikologi sebagai ilmu yang berdiri sendiri dimulai pada waktu Wilhelm Wundt (1832-1920) membuka laboratorium psikologi yang pertama pada tahun 1879 di Leipzig, Jerman. ${ }^{6}$

Psikologi sebagai suatu ilmu, maka psikologi merupakan pengetahuan yang diperoleh dengan penelitian-penelitian ilmiah. Penelitian ilmiah adalah penelitian yang dijalankan secara sistematis, terkontrol dan berdasarkan atas data empirik. ${ }^{7}$

${ }^{5}$ Ibid., h. 10.

${ }^{6}$ Ibid., h. 12.

${ }^{7}$ C.T. Morgan, dkk Introduction to Psychology, (Tokyo: McGraw-Hill, 
Suatu teori dalam ilmu dapat diuji dalam hal keajegannya dan keandalannya atau validitasnya. Ini berarti kalau penelitian ulang dilakukan oleh orang lain atau ahli lain, menurut langkah-langkah yang serupa dalam kondisi yang sama maka akan diperoleh hasil yang konsisten, yaitu hasil yang sama atau hampir sama dengan hasil yang terdahulu. Bila suatu teori atau hipotesis tidak dapat diuji (untestable), maka akan sulit hal itu dikatakan sebagai ilmu dan menurut Townsend (1953) eksplanasinya akan merupakan eksplanasi yang mistis (mystical explanation). ${ }^{8}$

Psikologi sebagai suatu ilmu memiliki tugas-tugas atau fungsi-fungsi tertentu seperti ilmu-ilmu pada umumnya. Adapun tugas psikologi adalah sebagai berikut :

a. Mengadakan deskripsi, yaitu tugas untuk menggambarkan secara jelas hal-hal yang dipersoalkan atau dibicarakan.

b. Menerangkan yaitu tugas untuk menerangkan keadaan atau kondisi-kondisi yang mendasari terjadinya peristiwa-peristiwa tersebut.

c. Menyusun teori yaitu tugas mencari dan merumuskan hukumhukum atau ketentuan-ketentuan mengenai hubungan antara peristiwa satu dengan peristiwa lain atau kondisi satu dengan yang lain.

d. Prediksi yaitu tugas untuk membuat ramalan (prediksi) atau estimasi mngenai hal-hal atau peristiwa-peristiwa yang mungkin terjadi atau gejala-gejala yang akan muncul.

e. Pengendalian yaitu tugas untuk mengendalikan atau mengatur peristiwa-peristiwa atau gejala. ${ }^{9}$

Psikologi merupakan suatu ilmu, maka dengan sendirinya psikologi memiliki ciri-ciri atau sifat-sifat seperti ilmu-ilmu yang lain. Berkaitan dengan hal tersebut, maka psikologi memiliki:

a. Obyek tertentu

b. Metode pendekatan atau penelitian tertentu.

c. Sistematis yang teratur sebagai hasil pendekatan terhadap

International Book Company, 1984), h. 6.

${ }^{8}$ Townsend, J.C, Introduction to Experimental Method, (Tokyo: McGraw-Hill Book Company, 1953), h. 83. Lihat juga Bimo Walgito, Pengantar Psikologi Umum, (Yogyakarta: Andi Offset, 2003), h. 2.

${ }^{9}$ Ibid., h. 3. 
obyeknya

d. Mempunyai riwayat atau sejarah tertentu

Obyek yang tertentu merupakan syarat mutlak dalam suatu ilmu, karena justru obyek itulah yang akan menentukan langkahlangkah lebih lanjut dalam rangka pembicaraan ilmu yang bersangkutan. Tanpa adanya obyek tertentu dapat diyakinkan tidak akan adanya pembahasan yang dapat dipertanggungjawabkan dari segi keilmuan. Suatu ilmu dapat dibedakan adanya obyek material dan obyek formal. Beberapa ilmu dapat memiliki obyek yang sama, tetapi tidak mungkin akan memiliki obyek formal sama, maka ilmu itu merupakan ilmu yang kembar, karena untuk dapat membedakan satu ilmu dengan ilmu yang lain terletak pada segi obyek formalnya. Obyek formal dari suatu ilmu tercermin dalam difinisi atau batasan dari ilmu yang bersangkutan.

Psikologi sebagai suatu ilmu, tidak lepas dari segi perkembangan psikologi itu sendiri serta ilmu-ilmu yang lain. Dari waktu ke waktu psikologi sebagai suatu ilmu akan mengalami perkembangan sesuai dengan perkembangan keadaan. Oleh karena itu psikologi sebagai suatu ilmu memiliki sejarah tersendiri hingga psikologi sampai dalam bentuknya sekarang ini. ${ }^{10}$ Pemikiran para ahli yang mungkin memiliki pandangan yang berbeda akan memacu perkembangan ilmu psikologi itu sendiri.

\section{Kaitan Psikologi Dengan Filsafat}

Ditinjau secara historis dapat dikemukakan bahwa ilmu yang tertua adalah lmu filsafat. Ilmu-ilmu yang lain tergabung dalam filsafat dan filsafat merupakan satu-satunya ilmu pada waktu itu, karena itu ilmu-ilmu yang tergabung dalam filsafat akan dipengaruhi oleh sifat-sifat dari filsafat. Demikian pula halnya dengan psikologi sebagai suat ilmu. Lama kelamaan disadari bahwa filsafat sebagai satu-satunya ilmu kurang dapat memenuhi kebutuhan manusia. Disadari bahwa hal-hal yang berhubungan dengan kehidupan tidak cukup lagi hanya diterangkan dengan filsafat, dengan demikian maka kemudian ilmu pengetahuan alam misalnya memisahkan diri dari filsafat dan berdiri sendiri sebagai

${ }^{10}$ Ibid., h. 4 
ilmu yang mandiri. Hal ini disebabkan karena ilmu pengetahuan alam membutuhkan hal-hal yang bersifat obyektif, yang bersifat positif dan ini tidak dapat dicapai dengan menggunakan filsafat termasuk pula psikologi. Psikologi yang awalnya bergabung dengan filsafat, akhirnya memisahkan diri dan berdiri sendiri sebagai suatu ilmu yang mandiri. Hal ini adalah jasa dari Wilhelm Wundt yang mendirikan laboratorium psikologi yang pertama pada tahun 1879 untuk menyelidiki peristiwa-peristiwa kejiwaan secara eksperimental. ${ }^{11}$

Perkembangan ilmu fisika dan ilmu kimia mempengaruhi tumbuhnya ilmu biologi. Salah satu dari ilmu biologi itu adalah ilmu perilaku, dalam kaitan ini maka psikologi merupakan salah satu yang termasuk dalam ilmu perilaku di samping antropologi dan sosiologi. ${ }^{12}$ Manusia sebagai mahluk hidup juga merupakan obyek dari filsafat yang antara lain membicarakan soal hakekat kodrat manuasia, tujuan hidup manusia dan sebagainya. Sekalipun psikologi pada akhirnya memisahkan diri dari filsafat, karena metode yang ditempuh sebagai salah satu sebabnya, tetapi psikologi masih tetap memiliki hubungan dengan filsafat. Bahkan sebenarnya ilmu-ilmu yang telah memisahkan diri dari filsafat itu tetap memiliki hubungan terutama mengenai hal-hal yang berkaitan dengan sifat hakekat serta tujuan dari ilmu pengetahuan itu.

\section{Pengertian Filsafat Dan Filsafat Ilmu}

Berfilsafat bukanlah monopoli para filsuf saja. Berfilsafat adalah menjadi perilaku setiap orang. Sadar atau tidak, kita masing-masing berfilsafat dengan suatu masalah fundamental dan menurut kita untuk memberi jawabannya secara konkret, baik dalam kedudukan kita sebagai individu maupun sebagai warga masyarakat ${ }^{13}$ Filsafat diartikan sebagai suatu cara berpikir yang radikal dan menyeluruh, suatu cara berpikir yang mengupas sesuatu sedalam-dalamnya. Tak satupun hal yang bagaimanapun

11 Ibid., h. 11.

12 Ibid. H. 13

13Kunto Wibisono, Pengertian Tentang Filsafat, makalah tidak diterbitkan, 2003. 
kecilnya terlepas dari pengamatan kefilsafatan. Tak ada suatu pernyataan yang bagaimanpun sederhananya yang kita terima begitu saja tanpa pengkajianyang seksama. Filsafat menanyakan segala sesuatu dari kegiatan berfikir kita dari awal sampai akhir seperti dinyatakan oleh Socrates, bahwa tugas filsafat yang sebenarnya bukanlah menjawab pertanyaan kita namun mempersoalkan jawaban yang diberikan. ${ }^{14}$

Tidak dapat dipungkiri bahwa "berfilsafat" sebagai manifestasi kegiatan intelektual yang telah meletakkan dasardasar paradigmatik bagai tradisi dalam kehidupan masyarakat ilmiah ala barat diawali oleh orang-orang Yunani kuno di abad ke-6 SM. Kelahiran filsafat tidak dirintis oleh dunia Timur, hal ini ditegakkan oleh Diogenes Leartius di tahun 200 yang kemudian diperkuat oleh Eduard Zeller dalam karyanya Grundriss der Geschichte der Grieschischen philosophie (1920), apa yang datang dari dunia Timur bukanlah filsafat melainkan ajaran-ajaran praksisterapan seperti ilmu perbintangan, ilmu pengobatan, ilmu hitung dan lain sebagainya.

Penegasan tersebut dapat kita pahami karena apa yang disebut ilmu pengetahuan diletakkan dengan ukuran, pertama pada dimensi fenomenalnya yaitu bahwa ilmu pengetahuan menampakkan diri sebagai masyarakat, sebagai proses dan sebagai produk. Kaidah-kaidah yang melandasinya, sebagaimana dikatakan oleh Robet Merton adalah universalisme, komunalisme, dis-interestedness dan skeptisme yang terarah dan teratur (organised scepticism). Kedua pada dimensi stukturalnya, yaitu bahwa ilmu pengetahuan harus terstruktur atas komponen-komponen, objek sasaran yang hendak diteliti (Gegantand), yang diteliti atau dipertanyakan tanpa mengenal titik henti atas dasar motif dan tata cara tertentu, sedangkan hasil temuannya diletakkan dalam satu kesatuan sistem.

Pada saat kelahirannya, ilmu pengetahuan yang identik dengan filsafat mempunyai corak mitologis dengan mana segala sesuatu yang ada dan yang mungkin ada diterangkan. Berbagai macam kosmogoni menjelaskan bagaimana kosmos dengan

${ }^{14}$ Suriasumantri, Tentang ..., h. 4 
berbagai aturannya terjadi dan dengan teogoninya diuraikan peranan para dewa yang merupakan unsur penentu terhadap segala sesuatu yang ada. Bagaimana corak mitologik ini telah mendorong upaya manusia untuk "berani' menerobos lebih jauh dunia pergejalaan, untuk mengetahui adanya sesuatu yang eka, tetap, abadi, dibalik yang bhineka, berobah dan sementara. ${ }^{15}$

Metode observasi, eksperimentasi dan komparasi yang dipelopori Francis Bacon (1561-1626) telah semakin mendorong pesatnya perkembangan ilmu pengetahuan dimana antara lain Helmoholtz, Pasteur, Darwin, Clerk Maxwell, berhasil menemukan hal-hal yang baru dalam penelitian ilmiahnya. Kesemuanya itu memberi isyarat bahwa dunia Barat telah berhasil melakukan tinggal landas untuk mengarungi dirgantara ilmu pengetahuan yang tiada bertepi. ${ }^{16}$

Ontologi ilmu meliputi ilmu itu, apa hakekat kebenaran dan kenyataan yang inheren dengan pengetahuan ilmiah, yang tidak lepas dari persepsi filsafat tentang apa dan bagaimana (yang) "ada" itu (being, Sein, het, zijn). Faham monisme yang terpecah menjadi idealisme atau spiritualisme, faham meterialisme, dualisme, pluralisme dengan berbagai nuansanya, merupakan faham ontologik yang pada akhirnya menentukan pendapat bahkan "keyakinan"kita masing-masing mengenai apa dan bagaimana (yang) “ada: sebagaimana manifestasi kebenaran yang kita cari.

Epistemologi ilmu, meliputi sumber, sarana dan tata cara menggunakan sarana tersebut untuk mencapai pengetahuan (ilmiah). Perbedaan mengenai pilihan landasan ontologik akan dengan sendirinya mengakibatkan perbedaan dalam menentukan sarana yang akan kita pilih. Akal (Verstand), akal budi (vernunft), pengalaman atau kombinasi antara akal dan pengalaman, institusi, merupakan sarana yang dimaksud dalam epistemologi, sehingga dikenal adanya model-model epistemologi seperti, rasionalisme, empirisme, kritisime atau rasionalisme kritis, positivisme, fenomenologi dengan berbagai variasinya, ditunjukan pula

${ }^{15}$ Kunto Wibisono, Hubungan Filsafat, Ilmu Pengetahuan dan Budaya, Makalah tidak diterbitkian, 2003

${ }^{16}$ Suriasumantri, Tentang..., h.3 
bagaimana kelebihan dan kelemahan sesuatu model epistemologi beserta tolak ukurnya bagi pengetahuan (ilmiah) itu sperti teori koherensi, pragmatis, dan teori intersubjektif.

Aksiologi meliputi nilai-nilai (values) yang bersifat normatif dalam pemberian makna terhadap kebenaran atau kenyataan sebagaiman kita jumpai dalam kehidupan kita yang menjelajahi berbagai kawasan, seperti kawasan sosial, kawasan simbolik ataupun fisik materil. Lebih dari itu nilai-nilai juga ditunjukan oleh aksiologi ini sebagai suatu conditio sine quanon yang wajib dipatuhi dalam kegiatan kita, baik dalam melakukan penelitian maupun di dalam menerapkan ilmu. Dalam perkembangan filsafat ilmu juga mengarahkan pada strategi pengembangan ilmu, yang menyangkut etik dan heuristik, bahkan sampai pada dimensi kebudayaan untuk menangkap tidak saja kegunaan atau manfaat ilmu, akan tetapi juga arti maknanya bagi kehidupan umat manusia. ${ }^{17}$

Filsafat ilmu bertugas memberi landasan filosofik untuk memahami berbagai konsep dan teori sesuai disiplin ilmu, sampai membekalkan kemampuan untuk membangun teori ilmiah, sehingga berwawasan luas, ada keterbukaan dan dapat saling memahami alur fikir ilmiah yang berbeda-beda. ${ }^{18}$

\section{E. Penelitian Psikologi Untuk Mencapai Hakekat Ilmu}

Penelitian merupakan rangkaian kegiatan ilmiah dalam rangka pemecahan suatu permasalahan dan merupakan upaya untuk mengembangkan ilmu. Hasil penelitian tidak pernah dimaksudkan sebagai suatu pemecahan (solusi) langsung bagi permasalahan yang dihadapi, karena penelitian merupakan bagian dari usaha pemecahan masalah yang lebih besar. Fungsi penelitian adalah mencarikan penjelasan dan jawaban terhadap permasalahan serta memberikan alternatif bagi kemungkinan yang dapat digunakan untuk pemecahan masalah. ${ }^{19}$ Sebagai suatu kegiatan ilmiah, penelitian memiliki karakteristik kerja ilmiah yaitu a. bertujuan, b. sistematik, c. terkendali, d. obyektif, e. tahan

\footnotetext{
${ }^{17}$ Wibisono, Hubungan ..., 2003.

${ }^{18}$ Noeng Muhajir, Filsafat Ilmu, (Yogyakarta: Rake Surasin, 2001), h. 2.

${ }^{19}$ Saiffudin Azwar, Metode Penelitian, (Yogyakarta: Pustaka Pelajar, 2003), h. 1.
} 
uji (verifiable).

Penelitian memilikitujuan.Maksudnya,kegiatan penelitian tidak dapat lepas dari kerangka tujuan pemecahan permasalahan. Walaupun penelitian tidak memberikan jawaban langsung terhadap permasalahan yang diteliti akan tetapi hasilnya harus mempunyai kontribusi dalam usaha pemecahan permasalahan. Hasil penelitian harus memberikan penjelasan akan fenomena yang menjadi pertanyaan penelitian dan harus dapat melandasi keputusan serta tindakan pemecahan permasalahan. Oleh karena itu, penelitian memiliki tujuan yang lebih luas dari pada sekedar melihat hubungan yang terjadi diantara variabel atau gejala yang diteliti.

Penelitian harus dilakukan secara sistematis. Artinya, langkah-langkah yang ditempuh sejak dari persiapan, pelaksanaan sampai kepada penyelesaian laporan penelitian harus terencana secara baik dan mengikuti metedologi yang benar. Kegiatan penelitian bukan kegiatan sambil lalu dan sama sekali bukan kegiatan kasual. Kualitas penelitian banyak ditentukan oleh ketepatan langkah metodologik yang digunakan. Oleh karena itu, tanpa adanya perencanaan yang baik maka kegiatan yang sistematik dan yang mengikuti standart metedologis tidak akan dapat dilakukan.

Penelitian harus dilakukan secara obyektif. Maksudnya, bahwa semua pengamatan, telaah yang dilakukan dan kesimpulan yang diambil oleh peneliti tidak boleh didasari oleh subjektivitas pandangan pribadi dan pengaruh kepentingan pihak lain. Hasil penelitian tidak boleh tercemar oleh pandangan subjektif peneliti ataupun oleh tekanan dari luar. Pengamatan dan telaah terhadap fenomena dan fakta yang berkaitan dengan permasalahan yang sedang diteliti haruslah dilakukan dengan objektif. Peneliti tidak boleh hanya mengumpulkan fakta yang mendukung praduga, asumsi dan teorinya saja, melainkan harus juga menelaah dan mengumpulkan fakta yang berlawanan sehingga bias dalam arah analisisnya dapat terhindarkan. Begitu pula penyimpulan pemikiran deduktif maupun induktif yang diperoleh oleh peneliti harus didukung oleh data yang berupa fakta objektif 
sehingga kesimupulan peneliti tidak diisi sekedar oleh apa yang diinginkan peneliti melainkan oleh apa yang ditemukan olehnya secara empirik.

Peneliti harus tahan uji. Maksudnya, penyimpulan penelitian harus merupakan hasil dari telaah yang didasari oleh teori yang solid dan metode yang benar sehingga siapapun yang akan melakukan replikasi penelitian termaksud tentu akan sampai pada kesimpulan yang serupa. Hasil penelitian akan lemah apabila berlakunya secara kondisional dalam situasi tertentu yang sempit. Namun demikian, penelitian yang tahan uji tidak berarti harus memiliki generalisasi yang luas. Penelitian-penelitian eksperimental seringkali aspek kelulusan generalisasi (validitas eksternal) dikalahkan oleh aspek keyakinan dan signifikansi perlakuan (validitas internal). ${ }^{20}$

Secara ontologis perkembangan psikologi sebenarnya telah mengalami kemajuan pesat, sehingga mampu menjawab ruang lingkup obyek yang dipelajarinya, yaitu perilaku. Landasan epistemologi ilmu tercermin secara operasional dalam metode ilmiah. Penelitian ilmiah adalah penelitian yang sistematik dan terkontrol berdasar metode ilmiah. Oleh karena itu pengetahuan ilmiah sangat dipengaruhi oleh teori-teori pengetahuan pada bidang ilmu seperti rasionalisme, empirisme, kritisisme, positivisme dan fenomenologi.

Dunia keilmuan di Barat, terutama ilmu-ilmu alam, banyak dipengaruhi oleh positivisme. Positivisme sebagai epistemologi berpendapat bahwa yang positif adalah yang konkret, nyata dan mengingkari metafisika (sesuatu yang abstrak). Metode yang digunakan dalam mencapai ilmu adalah observasi, eksperimen dan komparasi. Psikologi juga mengikuti jejak-jejak ilmu alam dengan menggunakan pendekatan tersebut, ini diamati dengan banyaknya penelitian psikologi menggunakan pendekatan kuantitatif. Para peneliti psikologi mengkuantifikasikan manusia dalam alat ukur, prosedur penelitian dan analisis data. Dapat dikatan bahwa psikologi sangat mendewakan pendekatan kuantitatif. ${ }^{21}$

\footnotetext{
${ }^{20}$ Ibid..., h. 2-4

${ }^{21}$ Yusti Rahayu, Perkembangan pendekatan kuantitatif dalam penelitian psikologi, Jurnal Anima, Volume 16 No 3, h. 316
} 
Secara ontologis, menurut pendekatan kuantitatif adalah menyusun bangunan ilmu nomothetik, yaitu ilmu yang berupaya membuat hukum dari generalisasinya. Kebenaran dicari lewat hubungan kasual. Secara aksiologis, penelitian kuantitatif adalah penelitian bebas nilai. Objektifitas terjaga dengan alat ukur dan berlaku dalam dimensi waktu dan tempat yang bebas. ${ }^{22}$

Di Indonesia, psikologi berkiblat pada psikologi Barat, sehingga penelitian-penelitian yang dilakukan saat ini lebih condong pada pendekatan kuantitatif. Banyak anggapan yang keliru bahwa pendekatan kuantitatif dengan teknik statistik merupakan pendekatan yang bergengsi dibanding pendekatan yang lain. Akibat lebih jauh adalah para peneliti banyak yang terlalu asyik dalam teknik-teknik statistik yang canggih dan tidak tahu filsafat yang mendasari terjadinya pendekatan kuantitatif beserta segala kelebihan dan keterbatasannya. ${ }^{23}$

Munurut Bakry, pemikiran positivisme menjadikan ilmu sosial bersifat positif dan empirik, mengakibatkan ilmu sosial dapat mengalalami kemajuan pesat. Psikologi bukan lagi sebatas pemikiran (yang tidak bisa dibuktikan) namun sudah tinggal landas dalam kenyataan, psikologi menjadi ilmu yang diharapkan dapat memecahkan problema manusia saat ini. Untuk dapat membuktikan secara empiris, perlu adanya suatu pengukuran. ${ }^{24}$

Keuntungan mengkuantifikasi objek psikologi dijelaskan oleh Nunnally: a) dengan pengukuran, setiap peneliti dapat melakukan pengukuran secara objektifdan dapat diuji oleh peneliti lain, b) pengukuran memungkinkan peneliti untuk melaporkan penelitiannya secara detil dan tepat. Pengukuran dengan angka memungkinkannya digunakan metode statistik, sehingga hasil suatu penelitian dapat lebih mudah dinilai, c) pengukuran memudahkan peneliti mengkomunikasikan hasil penelitiannya kepada peneliti lain, ${ }^{25}$ d) hunter dan Schimidt menambahklan bahwa pengkuantifikasian memungkinkan untuk dilakukannya metaanalisis yaitu penganalisisan kembali hasil-hasil penelitian

${ }^{22}$ Ibid , h. 321

${ }^{23}$ Muhajir, Filsafat..., h. 63

${ }^{24}$ Ibid., h. 64

${ }^{25}$ Nunnaly. J.C. Psychometric Theory, (New Delhi: Tata McGrawHill Publishing Com.Ltd), h. 6 . 
sehingga ditemukan suatu metafor.

Dengan menggunakan pendekatan kuantitatif, psikologi semakin banyak menjelaskan problema yang dihadapi manusia pada saat ini. Dalam bidang hukum misalnya, psikologi dapat menjelaskan mangapa polisi bertindak kejam terhadap tersangka kejahatan. Teori deindividuasi Zimbardo digunakan untuk menjelaskan bahwa manusia tidak kejam sejak lahir, melainkan peran polisi itulah yang menyebabkan seseorang itu menjadi kejam. Dalam bidang pendidikan, dengan menggunakan penelitian survey, teori intelegensi dapat menjelaskan pengaruhnya terhadap prestasi belajar, hal ini dapat dimungkinkan karena intelegensi maupun prestasi belajar dapat dapat dikuantifikasikan. Dengan menggunakan sampel penelitian, dimungkinkan generalisasi bahwa intelegensi barpengaruh terhadap prestasi belajar. Landasan berpikir epistemology dengan pendekatan kuantitatif yang bertujuan untuk membangun ilmu nomothetik memungkinkan hal tersebut terjadi. ${ }^{26}$

Secara aksiologis, penelitian kuantitatif dikatakan bebas nilai, hal ini tampaknya mulai dipertanyakan kembali, sehingga muncul psikologi lintas budaya. Deduksi dari teori Barat yang kita pakai mengakibatkan diperolehnya hipotesis bernuansa Barat yang akan dipaksakan pada keadaan empirik di Indonesia. Bagaimanapun ilmu tidak bebas nilai. ${ }^{27}$

Pada umumnya, para psikolog penganut aliran tingkah laku Barat dan mereka yang berorientasi pada eksperimen menyadari akan adanya pengaruh faktor kebudayaan dalam pembentukan tingkah laku subyek yang mereka pelajari. Namun amat sedikit dari mereka yang menyadari peran komponen ideologi dan sikap yang datang dari kebudayaan mereka, dan kemudian memberi warna pada pemahaman dan pengamatan mereka terhadap subyek penelitian mereka ini. ${ }^{28}$

Pengaruh positivistik mengakibatkan psikologi beranggapan bahwa objek formal psikologi adalah tingkah laku manusia,

${ }^{26}$ Ibid.h. 7

${ }^{27}$ Ibid ., h. 8

${ }^{28}$ Malik B. Badri, Dilema Psikolog Muslim, (Surabaya: Pustaka Firdaus, 1996), h. 3 . 
sesuatu yang dapat diamati. Asumsi ini sebenamya telah mendegradasi derajat manusia itu sendiri, karena manusia secara utuh tentunya bukan hanya tingkah laku.

Sejak masa Dilthey dan Weber sudah berulangkali digunakan istilah relativisme untuk menunjukkan anggapan mereka tentang kebenaran. Tidak ada suatu kebenaran tunggal yang tersedia bagi manusia atau yang "tinggal dipetik" begitu saja. Tanpa ada hentinya manusia mencari serta mewujudkan kebenarannya yang ditandai ruang dan waktu, secara konkret dalam masyarakat dan sejarah. Akhirnya lahirlah hermeneutik dengan penafsiran teks tertulis yang berasal dari lingkungan sosial dan historis yang berbeda dengan lingkungan dan dunia pembaca. Teori dan teknik hermeneutik dipengaruhi oleh filsafat bahasa yang dilatarbelakangi fenomenologi dan eksistensialisme mengenai kesatuan antara "isi pikir" dengan "pengungkapannya". Keduanya merupakan suatu kesatuan tunggal yang terwujud dalam bahasa. Tak mungkin isi dilepaskan dari pengungkapannya agar "isi yang sama" diungkapkan dengan bahasa yang baru atau yang lebih sesuai. Kedua unsur itu bersama-sama berubah atau berkembang sesuai dengan anggapan seseorang menuju kebenaran yang dirindukan dan diperlukan hati dan akal manusia pada setiap saat sesuai dengan keadaannya. ${ }^{29}$

Penelitian dengan pendekatan kualitatiflebih menekankan analisisnya pada proses penyimpulan deduktif dan induktif serta pada analisis terhadap dinamika hubungan antar fenomena yang diamati, dengan menggunakan logika ilmiah. Hal ini bukan berarti bahwa pendekatan kualitatif sama sekali tidak menggunakan dukungan data kuantitatif akan tetapi penekannya tidak pada pengujian hipotesis melainkan pada usaha menjawab pertanyaan penelitian melalui cara-cara berfikir formal dan argumentatif. ${ }^{30}$

Filsafat ilmu harus memperhatikan salah satu rautan khas ilmu modern: terus menerus mengubah bentuk nilai-nilai eksperimental menjadi nilai-nilai rasional dan sebaliknya, juga pengaruh timbal balik antara yang-apriori dengan yang-aposteriori.

${ }^{29}$ C. Verhaak \& Imam Haryono, Filsafat Ilmu Pengetahuan, (Yogyakarta: Kanisius, 2002), h. 175 - 177.

${ }^{30}$ Azwar, Metode..., h. 5. 
Di dalam ilmu yang menjadi masalah bukanlah pikiran antara sudut pandangan empirik atau sudut pandangan rasionalitik, melainkan empirisme, dan rasionalisme saling terikat secara tidak terpisahkan. Empirisme fakta-fakta harus dipahami, rasionalisme azas-azas harus diterapkan. Tidak ada fakta tanpa teori, tidak ada teori tanpa fakta. Filsafat ilmu hanya dapat berkembang secara dialektik di dalam keadaan saling mempengaruhi secara terus menerus antara momen rasional dengan momen empirk Karena itu filsafat ilmu - dan sejalan dengan itu segenap filsafat - mau tidak mau mempunyai struktur terbuka. Filsafat ilmu tidak pernah bersifat tertutup, melainkan senantiasa berkembang, seperti halnya kenyataan juga terus menerus mengalami perkembangan. Hal ini juga sekaligus memberikan penjelasan mengenai akal manusia. Akal tidak tanpa struktur, namun juga tidak sekali diterapkan untuk selamanya. Ia senantiasa dalam keadaan berkembang. Karena itu segenap pemikiran kefilsafatan serta ilmiah selalu bersifat sementara: setiap tahap merupakan persiapan bagi tahap berikutnya. Hal ini bukan merupakan alasan untuk tidak mempercayai pemikiran, karena justru dengan perkembangan ini pemikiran dapat tetap sesuai dengan akal yang senantiasa dalam keadaan berkembang. Salah satu tugas utama filsafat ilmu ialah menyelidiki sedalam-dalamnya yang kongkret. Dalam hal ini digunakan psikologi, yang pada hakekatnya merupakan metafisika mengenai hubungan antara akal manusia dengan kenyataan. ${ }^{31}$

\section{F. Penutup}

Penelitianilmiahmerupakan upaya untukmengembangkan ilmu. Apalagi institusi pendidikan yang mengedepankan riset sebagai tolak ukur suatu perkembangan ilmu. Penelitian dalam psikologi tidak akan pernah dapat lepas dari filsafat ilmu dengan landasan ontologi, epistemologi dan aksiologinya. Penelitian psikologi yang memiliki objek formal jiwa yang dimanifestasikan dalam perilaku menarik untuk dikaji sebagai suatu ilmu. Secara epistemologi, penelitian psikologi tampaknya terjebak dalam sikap positivisme, sehingga banyak penelitian psikologi

${ }^{31}$ Bernard Delgauw, Filsafat abad 20, (Yogyakarta: Tiara Wacana, 1988), h. 69. 
yang menggunakan pendekatan kualitatif Peneliti psikologi mengkuantifikasi manusia dalam alat ukur, prosedur penelitian dan analisis data, akibatnya psikologi agak kesulitan memahami manusia secara utuh dan menjadi dingin. Namun dengan adanya pendekatan kuantitatif tersebut, psikologi menjadi ilmu yang tidak lagi sebatas pemikiran manusia, tetapi sudah dapat tinggal landas dalam kehidupan nyata sehari-hari. Banyak masalah dapat dijawab secara baik oleh psikologi dengan munculnya psikologi terapan yang dibutuhkan manusia, misalnya penggunaan tes sebagai alat seleksi. Apa yang oleh satu pihak dielu-elukan sebagai pengilmiahan, oleh pihak lain ditolak sebagai "pemerosotan harkat manusia. Di sini filsafat dapat membantu untuk menemukandan memperlihatkan filsafat tersembunyi ${ }^{32}$ sebagai suatu, kebenaran. Sumbangan bagi pengembangan ilmu dan manfaat hasil penelitian bagi masyarakat menentukan nilai hasil penelitian. Hasil penelitian haruslah merupakan sumbangan yang berarti bagi pengembangan disiplin ilmu itu khususnya dan ilmu pengetahuan umumnya, serta dapat dirasakan manfaatnya oleh masyarakat sekarang maupun yang akan datang. "Kebahagiaan yang sebesar mungkin bagi jumlah manusia yang sebanyak mungkin"- suatu pendirian yang dinamakan hedonisme altruistik atau utilititianisme. ${ }^{33}$

Dari hal tersebut di atas peranan filsafat ilmu dalam penelitian dibidang psikologi adalah:

1. Mendampingi penggunaan hasil penelitian ilmu psikologi secara kritis sehingga peneliti mampu menggunakannya untuk kesejahteraan umat manusia.

2. Bahwasanya pendekatan kuantitatif dengan segala kelebihan dan keterbatasannya dapat ditambah dengan pendekatan kualitatif supaya lebih memahami hakekat manusia seutuhnya untuk mencapai kebenaran

3. Seorang peneliti hendaknya memiliki kejujuran sebagai etika dalam penelitian, sehingga hakekat ilmu yang tertinggi yaitu kebenaran akan tereapai. Fungsi etika tercapai jika kita menjadi kritis, karena ia memahami makna tuntutan-tuntutan

\footnotetext{
${ }^{32}$ Bertens, K, Panorama Filsafat modern, (Jakarta: Gramedia, 1987), h. 20.

${ }^{33}$ Louis O. Kattsoff, Pengantar Filsafat, (Yogyakarta: Tiara Wacana, 1983), h. 359.
} 
normatif dalam masyarakat sehingga dapat mengambil sikap dan mengintegrasikan ke dalam kepribadiannya. ${ }^{34}$

Namun hendaknya diingat bahwasanya ilmu juga memiliki keterbatasan-keterbatasan. Mereka yang mendewa-dewakan ilmu sebagai satu-satunya sumber kebenaran biasanya tidak mengetahui hakekat ilmu yang sebenamya. Demikian juga sebaliknya dengan mereka yang memalingkan muka dari ilmu, mereka yang tidak mau melihat kenyatan betapa ilmu telah membentuk peradaban seperti yang kita punyai sekarang ini, kepicikan seperti itu kemungkinan besar disebabkan karena mereka kurang mengenal hakekat ilmu yang sebenarnya.

Menghadapi dua pendapatyangyang ekstrim ini seyogyanya kita, harus berdiri di tengah dengan menyadari bahwa meskipun ilmu memang memberikan kebenaran namun kebenaran keilmuan bukanlah satu-satunya kebenaran dalam hidup kita ini. terdapat berbagai sumber kebenaran lain yang memperkaya khazanah kehidupan kita, dan semua kebenaran itu mempunyai manfaat asal diletakkan pada tempatnya yang layak.

Kebenaran terlalu rumit untuk dianalisis hanya oleh satu jalan pemikiran. Adalah ketinggihatian yang tidak mempunyai dasar sama sekali, bila kita, beranggapan bahwa ilmulah alpha dan omega dari kebenaran. Terdapat tempat masing-masing dalam kehidupan manusia bagi filsafat, seni, agama dan sebagainya disamping ilmu. Semuanya bersifat saling membutuhkan dan saling mengisi, seperti yang dikatakan oleh Einstein bahwa "ilmu tanpa agama adalah buta, dan agama tanpa ilmu adalah lumpuh." ${ }^{35}[]$

\section{Daftar Pustaka}

Azwar, Saiffudin, Metode Penelitian, Yogyakarta: Pustaka Pelajar, 2003

Badri, Malik B., Dilema Psikolog Muslim, Jakarta: Pustaka

${ }^{34}$ Franz Magnis Suseno, Berfilsafat dari konteks, (Jakarta: Gramedia Pustaka Utama, 1992), h. 14.

${ }^{35}$ Suriasumantri, Tentang..., h. 4. 
Firdaus,1996

Bertens, K., Panorama Filsafat Modern, Jakarta: Gramedia, 1987

Daldjoeni, N., Hubungan etika dengan ilmu dalam sebuah kumpulan karangan, tt.

Delgaauw, Bernard, Filsafat abad 20, Yogyakarta: Tiara Wacana, 1988

Dirgagunarsa, Singgih, Pengantar Psikologi, Jakarta: Mutiara, 1983

Jurnal Anima, Volume. XIII-No. 49, 1997

Jurnal Anima, Volume 16 No 3

Kattsoff, Louis O. , Pengantar Filsafat, Yogyakarta: Tiara Wacana, 1983

Morgan, CT., Introduction to Psychology, Tokyo: McGraw-Hill, International Book Company, 1984

Muhajir, Noeng, Filsafat Ilmu, Yogyakarta: Rake Surasin, 2001

Nunnaly, J.C., Pychometric Theory, New Delhi: Tata McGrawHill Publishing Co.Lmt, 1981

Suriasumantri, Jujun S., Tentang Hakekat ilmu, Jakarta: Yayasan Obor Indonesia, 1992

Suseno, Franz Magnis, Berfilsafat Dari Konteks, Jakarta: Gramedia Pustaka Utama, 1992

Townsend, JC. , Introduction to Experimental Method, Tokyo: McGrawHill Book Company, 1953

Walgito, Bimo, Pengantar Psikologi Umum, Yogyakarta: Andi Offset, Yogyakarta, 2003

Wibisono, Kunto, Pengertian tentang Filsafat, makalah, 2003 
M. Nursalim Malay

halaman ini bukan sengaja dikosongkan 